
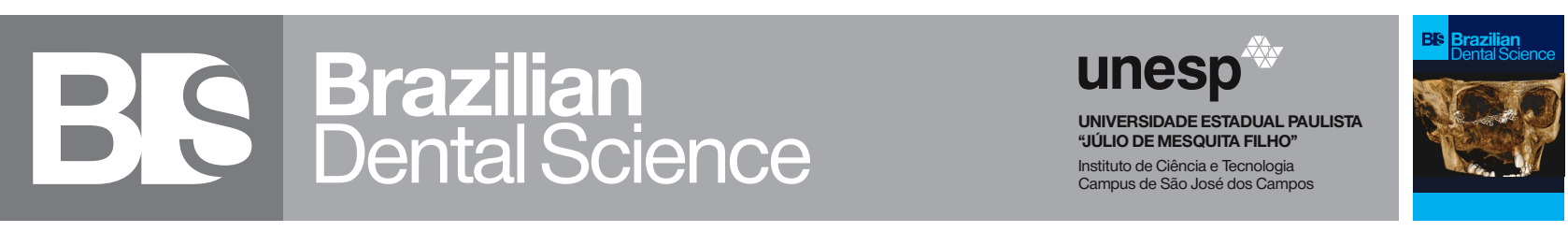

\title{
Animated video for increasing primary school teachers' knowledge regarding first aid management of dental avulsion
}

Vídeo animado para aumentar o conhecimento dos professores do ensino primário em relação ao tratamento de primeiros socorros em casos de avulsão dentária

\author{
Vassa Khema KATTHIKA ${ }^{1}$, Eva FAUZIAH ${ }^{2}$, Sarworini Bagio BUDIARDJO ${ }^{2}$ \\ 1 - Pediatric Dentistry Residency Program - Department of Pediatric Dentistry - Faculty of Dentistry - Universitas Indonesia - Jakarta \\ 10430 - Indonesia. \\ 2 - Department of Pediatric Dentistry - Faculty of Dentistry - Universitas Indonesia - Jakarta 10430 - Indonesia.
}

\section{ABSTRACT}

Introduction: Dental avulsion is a condition in which the tooth is completely dislodged from its socket. Inappropriate management when trauma occurs can complicate the prognosis of the tooth. The majority of injuries to children's teeth occur in the school environment and teachers play an essential role in providing first aid at the accident site. However, the school teacher's knowledge regarding first aid dental avulsion is inadequate. Objective: The purpose of this study was to analyze the effect of an animated video (First Aid Management of Dental Avulsion) on the knowledge of primary school teachers. Material and Methods: This clinical experimental study comprised 54 teachers from 13 public elementary schools in Central Jakarta who were chosen randomly to fill out a questionnaire before and after watching the animated video. Results: Data analysis using the Wilcoxon comparative test showed that there was a statistically significant increase $(\mathrm{P}<.05)$ in knowledge after watching the animated video. Conclusion: Thus, the animated video was effective in increasing the knowledge regarding first aid management of dental avulsion among the primary school teachers.

\section{KEYWORDS}

Audiovisual aid; First aid; School teachers; Tooth avulsion.

\section{RESUMO}

Introdução: a avulsão dentária é uma condição na qual o dente está completamente desalojado de seu alvéolo. O manejo inadequado quando ocorre um trauma pode complicar o prognóstico do dente. A maioria das lesões nos dentes das crianças ocorre no ambiente escolar onde os professores desempenham um papel essencial no fornecimento de primeiros socorros no local do acidente. No entanto, o conhecimento do professor em relação aos primeiros socorros diantedeumaavulsãodentáriaéinadequado. Objetivo: O objetivo deste estudo foi analisar o efeito de um vídeo animado (First Aid Management of Dental Avulsion) sobre o conhecimento de professores do ensino primário. Material e Métodos: Este estudo clínico experimental envolveu 54 professores de 13 escolas primárias públicas no centro de Jakarta, que foram escolhidos aleatoriamente para preencher um questionário antes e depois de assistir ao vídeo animado. Resultados: A análise dos dados por meio do teste comparativo de Wilcoxon mostrou que houve um aumento estatisticamente significativo $(\mathrm{P}<0,05)$ no conhecimento após assistir ao vídeo animado. Conclusão: Portanto, o vídeo animado foi eficaz em aumentar o conhecimento sobre o manejo de primeiros socorros da avulsão dentária entre os professores do ensino primário.

\section{PALAVRAS-CHAVE}

Auxílio audiovisual; Primeiros socorros; Professores de escola; Avulsão dentária. 


\section{INTRODUCTION}

$\mathrm{T}$ rauma can occur in both primary and permanent dentition in children. [1] Based on previous studies, the prevalence of dental trauma in children is $69.2 \%$. [2,3] One of the most serious types of dental trauma in children is dental avulsion. It is characterized by the dislodgement of the tooth from its socket, the collapse of the blood supply to the pulp, and exposure of the periodontal ligament cells to the external environment. [4] The main causes of avulsion are falls, injuries while exercising, and interpersonal violence. [5] The teeth most commonly affected by avulsion are the maxillary central incisors followed by the maxillary lateral incisors and mandibular central incisors. First aid management of dental avulsion is vital for a good prognosis; [6] inappropriate management can worsen the prognosis and lead to financial, psychological, and emotional problems. The dental treatment provided may last the lifetime of the patient. [7]

Dental trauma usually occurs at home or in school. [8] Based on existing studies, cases of dental trauma that occur in the school environment account for half of the total number of dental trauma cases. [9-13] Approximately $25 \%$ of school children around the world have experienced dental trauma. [3] This may be caused due to the involvement in physical activities (such as sports) and the time spent at school every day. [12] The school teacher is generally the first person at the scene immediately after the trauma occurs; hence, it is important to assess their awareness and knowledge in providing first aid to the child. $[11,14]$

First aid should be given when the injury occurs rather than when the patient first meets the dentist because it has an impact on the healing process. The earlier it is managed, the better the prognosis. [15,16] In many cases of dental avulsion, the child is referred to the dentist without first aid management at the accident site, thus leading to irreversible complications and consequences. [17] Therefore, school teachers, especially physical education teachers, play an important role in providing first aid management for dental avulsion to improve the prognosis of the traumatized teeth. Unfortunately, a large number of studies in several different countries have shown that the knowledge regarding first aid management of dental avulsion among school teachers is inadequate. [10,11,17] An audiovisual aid may aid in increasing this knowledge. Audiovisual aids have been shown to make the learning process more effective, concrete, realistic, and dynamic using senses of hearing and sight. [18] The video as an example of an audiovisual aid that has been used as a teaching tool for years.

The present study was aimed to analyze the effect of an animated video (First Aid Management of Dental Avulsion) on the knowledge of primary school teachers. It is expected that through the animated video, the knowledge and awareness of the school teachers might increase so that they can act correctly, quickly, and precisely when faced with cases of dental avulsion.

\section{MATERIAL AND METHODS}

This clinical experimental study was reviewed and approved by the Ethical Committee of The Faculty of Dentistry, University of Indonesia (22/Ethical Approval/ FKGUI/III/2019). The effect of the animated video First Aid Management of Dental Avulsion was carried out by providing the 6-10 teachers with a questionnaire before and after presenting a 4-min video in the class. The questionnaire itself was adapted from similar surveys that were conducted previously. [12,19-21] It was structured in the form of multiple-choice questions with each question containing options that were scored as follows: ideal answer-2 
points, acceptable answer-1 point, and incorrect answer-0 points.

Experts in the field ensured the validity of the prepared questionnaire and animated video before its administration. Changes to the questions, choices of answers, and the storyboard of the animated video were made according to their suggestions. Eventually, the questionnaire consisted of two sections: Section 1,-demographic details and Section 2,knowledge, which was simplified to only seven multiple-choice format questions. The reliability of the questionnaire as well as the animated video was determined on 30 respondents apart from the sample subjects.

The sample size was estimated at 49 using the paired sample t-test formula based on the following considerations: power, 95\% and significance level $\mathrm{C}, 5 \%$. The samples were selected using the consecutive sampling method. Primary public school teachers in Central Jakarta with a minimum education of Diploma IV or Bachelor's degree who had never received education regarding first aid management of dental avulsion were included in this study. The study was conducted in 13 public primary schools in Central Jakarta in April-May 2019. Public schools were chosen to maintain the same basic background; private schools might have different backgrounds in administering dental health education to the teachers.

All collected data were analyzed using SPSS version 22. Differences in the results before and after watching the animated video were calculated for each question and the questionnaire as a whole. The paired t-test/ Wilcoxon test was used to compare the individual knowledge score and to analyze the significant effect of the animated video on the knowledge of the primary school teachers.

\section{RESULTS}

The questionnaires were distributed to 13 randomly selected public primary schools. Fiftyfour school teachers who signed the informed consent were selected as sample subjects. Section 1 revealed that most of the subjects were women $(68.5 \%)$, with more than 20 years of service $(31.5 \%)$, and nonphysical education teachers $(88.9 \%)$ (Table I).

Table I - Demographic details.

\begin{tabular}{|cc|}
\hline Characteristic & $\mathbf{n}(\%)$ \\
Gender & \\
\hline Male & $17(31.5)$ \\
Female & $37(68.5)$ \\
\hline Age group & \\
s30 years & $11(20.4)$ \\
$31-40$ years & $16(29.6)$ \\
41-50 years & $11(20.4)$ \\
>50 years & $16(29.6)$ \\
\hline Education level & \\
\hline DiplomalV & $2(3.7)$ \\
\hline Bachelor's degree & $50(92.6)$ \\
Master's degree & $2(3.7)$ \\
\hline Length of service & \\
0-5years & $13(24.1)$ \\
6-10 years & $11(20.4)$ \\
11-20 years & $13(24.1)$ \\
\hline$>20$ years & $17(31.5)$ \\
\hline Field of education & \\
\hline Non-physical education & $48(88.9)$ \\
Physical education & $6(11.1)$ \\
\hline
\end{tabular}

The measurement of the primary school teachers' knowledge score was carried out before and after watching the animated video on first aid management of dental avulsion. An analysis of the scores before watching the animated video showed that the teachers had insufficient knowledge regarding dental avulsion (Table II). 
Table II - Comparison of individual knowledge score before and after watching the animated video.

\begin{tabular}{|c|c|c|c|c|c|c|c|c|}
\hline \multirow{2}{*}{ No } & \multirow{2}{*}{ Questions } & \multicolumn{3}{|c|}{ Score before watching $n(\%)$} & \multicolumn{3}{|c|}{ Score after watching $n(\%)$} & \multirow[t]{2}{*}{$p$} \\
\hline & & 0 & 1 & 2 & 0 & 1 & 2 & \\
\hline 1. & $\begin{array}{l}\text { Arif's front left upper tooth which avulsed } \\
\text { due to falling is... }\end{array}$ & $\begin{array}{c}33 \\
(61.1)\end{array}$ & NA & $\begin{array}{c}21 \\
(38.9)\end{array}$ & $\begin{array}{c}13 \\
(24.1)\end{array}$ & NA & $\begin{array}{c}41 \\
(75.9)\end{array}$ & $0.0001^{\star}$ \\
\hline 2. & $\begin{array}{c}\text { Which of the following actions do you } \\
\text { consider as the first aid management } \\
\text { after avulsion? }\end{array}$ & $\begin{array}{c}29 \\
(53.7)\end{array}$ & $\begin{array}{c}22 \\
(40.7)\end{array}$ & $\begin{array}{c}3 \\
(5.6)\end{array}$ & $\begin{array}{c}2 \\
(3.7)\end{array}$ & $\begin{array}{c}32 \\
(59.3)\end{array}$ & $\begin{array}{c}20 \\
(37.0)\end{array}$ & $0.0001^{\star}$ \\
\hline 3. & Can Arif's avulsed tooth be replanted? & $\begin{array}{c}45 \\
(83.3)\end{array}$ & NA & $\begin{array}{c}9 \\
(16.7)\end{array}$ & $\begin{array}{c}4 \\
(7.4)\end{array}$ & NA & $\begin{array}{c}50 \\
(92.6)\end{array}$ & $0.0001^{\star}$ \\
\hline 4. & $\begin{array}{l}\text { What type of health care are you looking } \\
\text { for first? }\end{array}$ & $\begin{array}{c}8 \\
(14.8)\end{array}$ & $\begin{array}{c}37 \\
(68.5)\end{array}$ & $\begin{array}{c}9 \\
(16.7)\end{array}$ & $\begin{array}{c}4 \\
(7.4)\end{array}$ & $\begin{array}{c}35 \\
(64.8)\end{array}$ & $\begin{array}{c}15 \\
(27.8)\end{array}$ & $0.025^{\star}$ \\
\hline 5. & How do you carry the avulsed tooth? & $\begin{array}{c}46 \\
(85.2)\end{array}$ & $\begin{array}{c}8 \\
(14.8)\end{array}$ & $\begin{array}{c}0 \\
(0)\end{array}$ & $\begin{array}{c}9 \\
(16.7)\end{array}$ & $\begin{array}{c}32 \\
(59.3)\end{array}$ & $\begin{array}{c}13 \\
(24.1)\end{array}$ & $0.0001^{\star}$ \\
\hline 6. & $\begin{array}{l}\text { What storage medium do you use to carry } \\
\text { the avulsed tooth? }\end{array}$ & $\begin{array}{c}39 \\
(72.2)\end{array}$ & $\begin{array}{c}13 \\
(24.1)\end{array}$ & $\begin{array}{c}2 \\
(3.7)\end{array}$ & $\begin{array}{c}2 \\
(3.7)\end{array}$ & $\begin{array}{c}21 \\
(38.9)\end{array}$ & $\begin{array}{c}31 \\
(57.4)\end{array}$ & $0.0001^{\star}$ \\
\hline 7. & $\begin{array}{l}\text { When is the best time to replant the } \\
\text { avulsed tooth so that the success rate of } \\
\text { the treatment is high? }\end{array}$ & $\begin{array}{c}31 \\
(57.4)\end{array}$ & NA & $\begin{array}{c}23 \\
(42.6)\end{array}$ & $\begin{array}{c}18 \\
(33.3)\end{array}$ & NA & $\begin{array}{c}36 \\
(66.7)\end{array}$ & $0.009^{*}$ \\
\hline
\end{tabular}

- Wilcoxon test, ${ }^{*} P<.05$

- NA (not available)

- Question 1, 3, and 7 has only 1 correct answer. Score $0=$ incorrect answer; Score $2=$ ideal answer.

- Question 2, 4, 5, and 6 has $>1$ correct answer. Score 0 = incorrect answer; Score 1 = acceptable answer; Score $2=$ ideal answer.

Then, the measurement of the total score of the primary school teachers' knowledge was carried out before and after watching the animated video. As the Kolmogorov Smirnov's normality test showed that the data distribution was not normal, the Wilcoxon test was used to analyze the effect of the animated video on the knowledge of the primary school teachers. All subjects $(n=54)$ demonstrated a statistically significant increase $(\mathrm{P}<.0001)$ in the total knowledge score after watching the animated video (Table III).

Table III - Comparison of total knowledge score before and after watching the animated video.

\begin{tabular}{|cccc|}
\hline Total knowledge score & $\mathbf{n}$ & $\begin{array}{c}\text { Median } \\
\text { (Minimum-maximum) }\end{array}$ & $\mathbf{p}$ \\
\hline Total score before & 54 & $3(0-13)$ & $0.0001^{\star}$ \\
\hline Total score after & 54 & $10(4-14)$ & \\
\hline
\end{tabular}

\section{DISCUSSION}

In the present study, an increase in the primary school teachers' knowledge after watching the animated video (First Aid
Management of Dental Avulsion) was observed (Table II). In addition, a significant difference $(\mathrm{P}<.0001)$ between the total scores before and after watching the animated videos was noted (Table III).

The highest increase in score was observed for the question regarding the replantation of the avulsed permanent tooth. The number of teachers who answered this question correctly sharply increased from $9(16.7 \%)$ before watching the video to 50 (92.6\%) after watching the video $(\mathrm{P}<.0001)$. This is in line with the research conducted on the effectiveness of audiovisual aids on the knowledge of school teachers about emergency management of dental trauma; the percentage of teachers who answered that avulsed teeth could be replanted was increased from $68.4 \%$ to $99 \%$ in that study. [12]

The second-highest increase in knowledge was demonstrated for the storage medium used to carry the avulsed tooth. Initially, only $2(3.7 \%)$ teachers answered this question correctly; however, after watching the video, the 
number was increased to 31 (57.4\%). Similar results were found in a study using educational posters and leaflets regarding dental injury management. After seeing the educational poster, $100 \%$ of school teachers chose milk as a temporary storage medium for the avulsed tooth, [16] whereas school teachers who were informed using educational leaflets, an increase from $10 \%$ to $86.6 \%$ were seen. [22]

A significant difference in the measurement of the total score of the school teachers' knowledge before and after watching the animated video was observed in this study $(\mathrm{P}<.0001)$. Similar results were obtained in a previous study where a video used as an audiovisual education aid proved to be effective in increasing the school teachers' knowledge regarding dental trauma in children. [12] The main advantage of the video was better visualization and the ability to repeat if needed. Video recordings were as effective as live demonstrations for teaching skills, clinical methods, and practical techniques. [23]

The concept of first aid management of dental avulsion that must be carried out by the teacher was emphasized with detailed steps in accordance with the International Association of Dental Traumatology guidelines. [6] Firstly, make sure that the avulsed tooth is a permanent tooth and try to locate it. Hold the tooth at the crown; avoid holding it at the root. If the tooth is dirty, wash it briefly under running water. It is stated that there are three choices for the type of storage medium to use, i.e., fresh milk, patient's saliva, and Hank's Balanced Salt Solution. In the case of the patient's saliva, the tooth should be stored in the patient's mouth by placing under the tongue or on the inside of the cheek. However, for young patients, it is not recommended to do so because the tooth can be swallowed. In addition, suggestions for controlling the bleeding by biting on a sterile gauze have been provided. This is because, in most cases, soft tissue bleeding in the oral cavity is one of the main sources of panic. Finally, the tooth that has been stored in the storage medium should be taken to the dentist as soon as possible to be replanted. This results in a good prognosis. The two main factors that influence the success of replantation are extraoral dry time and physiologic storage medium. [17]

The character described in the animated video was a primary schoolboy (Arif) because it corresponds to the literature, which states that boys experience more trauma to permanent teeth than girls with a ratio of 1.3-2.5:1. $[13,15,24]$ The tooth that had avulsed in the video was a maxillary left anterior tooth. The teeth most commonly affected by avulsion are the maxillary central incisors followed by the maxillary lateral incisors and mandibular central incisors. In the case of permanent teeth, avulsion is more common in children aged 7-9 years because the central incisors are developing at this age; moreover, the periodontal ligament and alveolar bone are immature and unable to provide adequate resistance to the extrusive forces. [5]

The duration of the 4-min animation video was adjusted to the results of a large-scale study conducted by the Massachusetts Institute of Technology, which found that the optimal video length was $6 \mathrm{~min}$ or shorter; short-duration videos were found to be far more interesting than videos longer than 6 min. [25]

The selection of the animation with spoken text information in the video aimed to make the information delivered better and easier to remember. A cognitive theory about multimedia learning suggested that people have separate channels for processing visual and audio information. Both these channels were expected to have limits on their respective processing capacity, which meant that information presented in dual mode (visual and audio) was better stored in memory than that presented in single mode. An animation consists of oral texts and visual images (dual mode). Thus, the 
information will be easier to process, stored in memory, and retrieved later on. Furthermore, information that is easily processed will make the individual more positive toward it. Thus, the primary school teachers were expected to have a more positive attitude toward information that was easily processed. [26]

The animated video used in the current study was the first educated animation video in the Indonesian language. Therefore, dental professionals have more options for the provision of dental health education regarding dental trauma, particularly, dental avulsion. In this study, the questionnaire was administered directly after the animated video was presented. However, the long-term effect of the video has not analyzed because the video was presented only once. In the future, it would be interesting to measure the school teachers' knowledge after a longer period of time.

\section{CONCLUSION}

In this study, significant differences in primary school teachers' knowledge regarding first aid management of dental avulsion were observed before and after watching the animated videos. Thus, it can be concluded that the animated video (First Aid Management of Dental Avulsion) was effective in increasing the knowledge of the primary school teachers. This video was very effective in increasing the school teachers' knowledge regarding first aid management of dental avulsion in children. As elementary school teachers' knowledge regarding avulsion management increase, it is expected that children who have experienced dental trauma can be handled immediately, this resulting a good prognosis.

\section{Acknowledgments}

The authors would like to thank all the principals from each school who participated in this study. Also to HIBAH PITTA Universitas
Indonesia which has financially supported this study.

\section{Conflict of Interest}

The authors confirm that they have no conflicts of interest.

\section{REFERENCES}

1. DutraFT, Marinho AM, Godoi PF,Borges CM, Ferreira EF,Zarzar PM. Prevalence of dental trauma and associated factors among 1- to 4-year-old children.J Dent Child (Chic). 2010 Sep-Dec;77(3):146-51. PMID: 22044467.

2. Rodrigues Campos Soares T, de Andrade Risso P,Cople Maia L. Traumatic dental injury in permanent teeth of young patients attended at the federal University of Rio de Janeiro, Brazil. Dent Traumatol. 2014 Aug;30(4):312-6. doi: 10.1111/edt.12087.Epub2013Dec2.PMID:24289752

3. Zhang Y,Zhu Y,Su W, Zhou Z, Jin Y, Wang X. A retrospective study of pediatric traumatic dental injuries in X'an, China. Dent Traumatol. 2014 Jun;30(3):211-5. doi: 10.1111/edt.12075. Epub2013 0ct3. PMID: 24118923.

4. Andreasen J0, Andreasen FM, Andersson L. Textbook and Color Atlas of Traumatic Injuries to the Teeth. 4th ed. Copenhagen: Blackwell Munksgaard; 2007.

5. McCafferty J, O'Connell AC. Treatment of the avulsed anterior tooth. J Ir Dent Assoc. 2011Dec-2012 Jan;57(6):319-22. PMID: 22338287.

6. Andersson L, Andreasen J0, Day P, Heithersay G, Trope M, Diangelis AJ, Kenny DJ, Sigurdsson A, Bourguignon C, Flores MT, Hicks ML, Lenzi AR, Malmgren B, Moule AJ, Tsukiboshi M; International Association of Dental Traumatology. International Association of Dental Traumatology guidelines for the management of traumatic dental injuries: 2 . Avulsion of permanent teeth. Dent Traumatol. 2012 Apr;28(2):88-96. doi: 10.1111/j.1600-9657.2012.01125.x. PMID:22409417.

7. Levin L, Zadik Y. Education on and prevention of dental trauma: it's time to act! Dent Traumatol. 2012Feb;28(1):49-54. doi:10.1111/j.1600-9657.2011.01060.x. Epub2011Sep 5.PMID:21895972.

8. Murali K, Krishnan R, Kumar VS, Shanmugam S, RajasundharamP.Knowledge, attitude, and perception of mothers towards emergency management of dental trauma in Salem district, Tamil Nadu: a questionnaire study. J Indian Soc Pedod Prev Dent. 2014 Jul-Sep;32(3):202-6. doi: 10.4103/0970-4388.135825. PMID: 25001438.

9. Unal M, Oznurhan F,Kapdan A, Aksoy S, Dürer A. Traumatic dental injuries in children. Experience of a hospital in the central Anatolia region of Turkey. Eur J Paediatr Dent. 2014 Mar;15(1):17-22.PMID:24745587.

10. GravinaD, Peruchi C, Rivera G, Santos, VRNC. Traumatic Dental Injury: A Case Report. J Trauma Treat. 2015;2(15):2-5. doi:10.4172/2167-1222.S2-015

11. Attarzadeh H, Kebriaei F, Sadri L, Foroughi E, Taghian M. Knowledge and Attitudes of Elementary Schoolteachers on Dental Trauma and its Management in Yazd, Iran. J Dent(Shiraz). 2017 Sep;18(3):212-218. PMID: 29034277;PMCID:PMC5634362.

12. Niviethitha S, Bhawarlal C, Ramkumar H,Dhakshanamoorthy S, Shanmugam H. Effectiveness of an audio-visual aid on the knowledge of school teachers regarding the emergency management of dental injuries. Dent Traumatol. 2018 Apr 19. doi: 10.1111/edt.12405. Epub ahead of print. PMID: 29676046. 
13. Andersson L Epidemiology of traumatic dental injuries.JEndod. 2013 Mar;39(3 Suppl):S2-5. doi: 10.1016/j.joen.201211.021. PMID:23439040.

14. Shamarao S, Jain J, Ajagannanavar SL, Haridas R, Tikare S, Kalappa AA. Knowledge and attitude regarding management of tooth avulsion injuries among school teachers in rural India. J Int Soc Prev Community Dent.2014 Nov;4(Suppl1):S44-8. doi:10.4103/2231-0762.144599.PMID:25452927;PMCID: PMC4247550.

15. Lam R. Epidemiology and outcomes of traumatic dental injuries: a review of the literature. Aust Dent J.2016 Mar;61 Suppl 1:4-20. doi: 10.1111/adj.12395. PMID: 26923445 .

16. Ghadimi S, Seraj B, KeshavarzH, Shamshiri AR, Abiri R. The effect of using an educational poster on elementary school health teachers' knowledge of emergency management of traumatic dental injuries. J Dent(Tehran). 2014 Nov;11(6):620-8. Epub 2014 Nov 30. PMID:25628691; PMCID:PMC4281183.

17. Siddiqui AA, Alhobeira HA, Altamimi YS, Al-Amer NS, Alsaleh MK, Mirza AJ. Dental Trauma:School Teachers' Understanding of Handling the Situation. Int J Contemp Med Res. 2017;4(2):512-4.

18. Ashikuzzaman M. Importance of Audio Visual Materials in Teaching and Learning. Avms. 2013

19. Bayrak S, Tunc ES, Sari E. Evaluation of elementary school teachers' knowledge and attitudes about immediate emergency management of traumatic dental injuries. Oral Health Prev Dent. 2012;10(3):253-8. PMID: 23094268.

20. Catilo D, Faustorilla M, Jin A, Gardner SP. South Australian Primary and Secondary School Teachers' Knowledge and Attitude Toward Dental Trauma Management: An Investigative Report Leading to The Development of Educational Strategies to Enhance Awareness. Aust New Zeal J Dent Oral Heal Ther.2019;7(2):18-24.
21. Singh M, Ingle NA, Kaur N, Yadav P.Evaluation of knowledge and attitude of school teachers about emergency management of traumatic dental injury. Jint Soc Prev Community Dent 2015 Mar-Apr:5(2):108-13. doi:10.4103/22310762.155735.PMID:25992335; PMCID:PMC4415328.

22. Arikan V, Sönmez H. Knowledge level of primary school teachers regarding traumatic dental injuries and their emergency management before and after receiving an informative leaflet. Dent Traumatol. 2012 Apr;28(2):101-7. doi: 10.1111/.j.1600-9657.2011.01042.x. Epub 2011 Jul 26. PMID:21790991.

23. Shah N, Mathur VP, Kathuria V, Gupta T. Effectiveness of an educational video in improving oral health knowledge in a hospital setting. Indian JDent 2016 Apr-Jun;7(2):70-5. doi:10.4103/0975-962X.184646. PMID:27433049;PMCID: PMC4934091.

24. Erlinda D, Rizal MF.Repair of Class IV Ellis Fracture in The PermanentCentral Incisor With a Crown Restoration and Fiberglass Post. J Int Dent Med Res. 2017;10(Specialissue):830-3.

25. Guo PJ, Kim J, Rubin R. How video production affects student engagement: An Empirical Study of MOOC Videos. Proc first ACM Conf Learn scaleConf -LS '14. 2014;41-50. doi:10.1145/2556325.2566239

26. Meppelink CS, van Weert JC, Haven CJ, Smit EG. The effectiveness of health animations in audiences with different health literacy levels: an experimental study. J Med Internet Res. 2015 Jan 13;17(1):e11. do: 10.2196/jmir.3979. PMID: 25586711;PMCID:PMC4319081.

\section{Eva Fauziah}

(Corresponding address)

Department of Pediatric Dentistry, Faculty of Dentistry, Universitas Indonesia

J1. Salemba Raya No.4, Jakarta Pusat, Jakarta 10430, Indonesia

Date submitted: 2020 Mar 27

E-mail: eva.fauziah@ui.ac.id 